\title{
Does the Basic Christian Community (BCC) need to do Financial Accountability to the Parish?
}

\author{
Maria Yessica Halik ${ }^{1}$, Johannes Baptista Halik ${ }^{2}$ \\ Department of Accounting, Universitas Kristen Indonesia Paulus, Indonesia ${ }^{1}$ \\ Department of Management, Universitas Kristen Indonesia Paulus, Indonesia ${ }^{2}$ \\ \{marjesshalik@ukipaulus.ac.id $\left.{ }^{1}\right\}$
}

\begin{abstract}
Purpose: This study purposed to provide insights regarding the importance of financial report and accountability made by Basic Christian Communities (BCCs) (in Indonesia it is called: rukun or lingkungan) and to provide an understanding of the phenomena felt by people who prepared BCCs financial reports and parish financial reports.Methodology: The researchers used a qualitative method with the phenomenology approach to describe a phenomenon that occurs in the preparation of financial report at each BCCs. Under this strategy, the researchers interviewed the parties who have experiences in preparing BCCs financial statements. The research was carried out at one of the Arch Dioceses of Makassar, which will be called X Parish. Interview conducted with the priest, treasurer, and five to ten leaders and treasurers from $\mathrm{BCC}$ who are willing to give their opinion and experiences. Results: it was found that the $\mathrm{BCC}$ has an obligation to make financial reports and report it to the parish. However, based on the results of interviews with the chairperson and treasurer of the BCCs, some BCCs still refused. Training and assistance from the parish are provided to BCCs member to increase their understanding of the importance of financial reporting.
\end{abstract}

Keywords: Financial Accountability; Catholic; Basic Christian Communities

\section{Introduction}

Financial accountability in agencies or non-profit organizations has become an issue that often arises nowadays. This occurs due to the increasing misuse of assets and other frauds committed by the management of the organisational. Therefore, financial and asset reporting rules and procedures are needed for each non-profit organization to be accountable for the organization's financial management to stakeholders [1]. In Indonesia, the Indonesian Institute of Accountants (IAI) establishes financial reporting standards for non-profit organizations which are summarized in the Statement of Financial Accounting Standards (SFAS) No. 45. This standard becomes the main guideline for non-profit organizations, such as the Church to formulate financial reporting regulations that must be applied by churches in Indonesia [2].

The church, as an example of a non-profit organization, has an obligation to manage its finances and assets. The implementation of this financial management is a form of the Church's responsibility to God and to others [3]. As stated in Kaslyn [4], one of the statements 
from the bishops of the United States emphasizes the importance of being responsible for every human being to God and others. Good responsibility from the Church can improve internal controls, especially by establishing segregation of duties, recording of financial transactions, and authorising the disbursement of funds [5]. Recently, many scandals that occurred which related to the Catholic Church demand the church to provide and report the use of church assets transparently. Catholic dioceses and parishes are required to exercise internal control in the financial sector, the mechanism of which is regulated in Canon Law. West and Zech's research found that the more diocese reports their financial data, the easier it is to detect fraud [6].

This issue has become one of the main concerns of the Arch Diocese of Makassar, where one of the missions resulting from the Diocesan Synod meeting in 2012 is: "to seek professional, transparent and accountable governance of all Church assets for good pastoral care". This mission motivates the diocese to establish Financial and Accounting Guidelines for every Parish located in Makassar, South, West, and Southeast Sulawesi. These guidelines assist every parishes to manage the Church properties. In accordance with the Code of Canon Law No. 1254, it is stated that the ownership and management of ecclesiastical assets is aimed at the interests of worship services, the lives of servants, the work of holy apostleship and charity and concern for those who are in need.

Before discussing how parishes should manage the church assets, it is important to understand the parts of the parish itself. According to the Code of Canon Law, which was revealed in the Basic Guidelines for Parish Pastoral Councils, parishes are made up of various ecclesial groups, including Basic Christian Communities/BCCs (in Indonesia it is called: 'rukun' or 'lingkungan'). A BCC is used as an agent of evangelization by the Catholic Church, whose members consist of several families living in the same neighbourhood [7].

$\mathrm{BCC}$ contributes to helping the parish to deal with its objectives and assisting the parish to align with all strategies to achieve its objectives [8]. BCC as part of the parish carries out all its activities on behalf of the parish. This means that all BCC's activities must be in line with the purpose of worship and service. If $\mathrm{BCC}$ uses and manages properties and assets in all its activities, it means that $\mathrm{BCC}$ is obliged to be responsible for the use and management of these assets because they are the property of the Church. Therefore, as a preventive measure to avoid ecclesiastical financial problems, especially in Parishes within the Arch Diocese of Makassar, the Parish Financial and Accounting Guidelines (IND: Pedoman Keuangan dan Akuntansi Paroki) were issued. The fundamental principle that needs to be realized is that in the Church the only goal is God, while money and material are only tools, which requires responsibility in the management of these facilities.

This guideline needs to be implemented by the Parish and all related units or groups in a Parish, including BCCs. As stated in the guideline, the scope of parishes finances is financial management of the church station, BCCs, and categorical groups which are parts of the parish. Hence, every unit in the parish is obliged to make a financial report to account for the various liturgical activities and services that occur in that unit. This guideline has valid since 2013. However, many parishes have not implemented their financial reporting according to the guidelines. Finally, since the middle of 2019, the Arch Diocese of Makassar has started promoting the implementation of these guidelines; even though there are still many obstacles occurred. This study was established to provide in-depth examination to reveal the causes of these obstacles and the reasons for BCCs refusing to submit their financial reports to the parish. Research objectives: 1) to provide insights regarding the importance of financial report and accountability made by Basic Christian Communities (BCCs) (in Indonesia it is called: 
rukunor lingkungan); 2) to provide an understanding of the phenomena felt by people who prepared BCCs financial reports and parish financial reports.

\section{Methodology}

This paper adopted qualitative method with the phenomenology approach to describe a phenomenon that occurred in the preparation of financial report at each BCCs. Researchers as part of X Parish and one of members of the Financial Report Analyst Team of the Arch Diocese of Makassar, wanted to understand the experiences felt by each BCCs in making their financial reports. Using the procedure for conducting phenomenological research developed by Pollio, Henley, and Thompson [9], the researcher first selects the topic according to the phenomenon that occurs, and then conducts bracketing interviews to clearly determine the respondent's opinion regarding the problem. At this stage, the participants are the focus, so the researcher will not ask questions that lead to certain opinions. After all participants' answers have been collected, the researcher makes a transcript of the interview results and summarizes it into categories that correspond to the research problem [10]. Before starting a research report, the researcher reconfirmed the summary answers to the respondents.

The research was carried out at one of the Arch Dioceses of Makassar, which will be called X Parish. Interview conducted with the priest, treasurer, and five to ten leaders and treasurers from BCC who are willing to give their opinion and experiences. All their name will be disguised, and fake names will be used instead. If there are similarities in the abbreviations, they are purely coincidental. The discussion and results from this study are based on the real experiences of the related people above to create financial report in accordance with the Arch Diocese of Makassar.

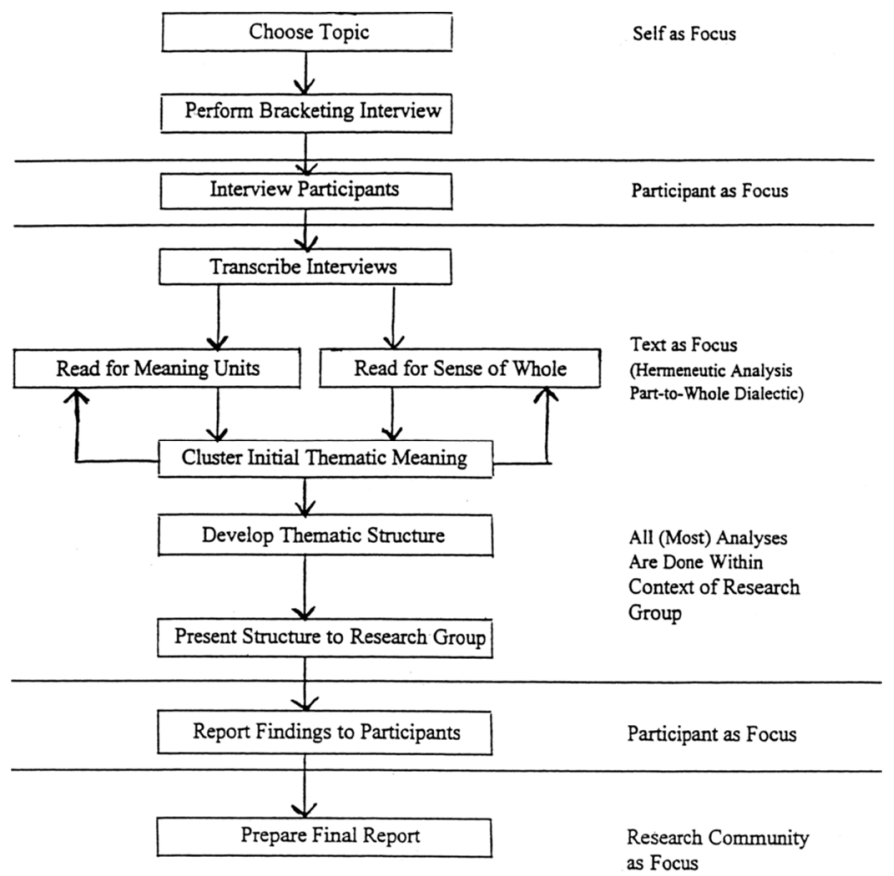

Fig. 1. Methodology using Phenomenology Approach 


\section{Result and Discussion}

According to the Parish Financial and Accounting Guidelines of the Arch Diocese of Makassar, BCC is a part of the parish, region, or station, which should consist of 20-40 families for the effectiveness of pastoral services [11]. As mentioned earlier, interviews were conducted to collect data in the form of opinions from BCCs financial report compilers and related parties, such as parish treasurers and parish priests. Based on the results of the interview, several important topics related to research problems can be summarized, including:

\section{a) Financial Supervision}

According to article 6 of the Parish Financial and Accounting Guidelines of the Arch Diocese of Makassar, financial supervision is carried out by the Financial Team of the Arch of Diocese when necessary. The team is formed based on the order of the Diocesan to supervise, guide, and oversee the financial management and assets of the Parish. Financial supervision includes all aspects of financial management including the Church's assets [11].

Therefore, an interview was conducted with a Pastor from X Parish in which he stated:

"Since I become the Pastor for the parish in 2019, the financial team of the Arch Diocese of Makassar has never conducted a visit to provide guidance in the preparation of financial reports. As far as I am aware, there was a training in 2016 which was conducted by the previous team to the parish's treasurer".

This statement aligned with an interview that was attended by one of the X Parish's treasurer which stated that during the previous period, she was trained by the financial team of the Arch Diocese to prepare financial report for the parish.

\section{b) Person in Charge of Parish's Financial}

Canon 532 and 537 of the 1983 Code of Canon Law stated that in order to create good transparency and accountability regarding the use of parish assets, it requires responsibility from the parish priest. In this case, the parish priest acts as a steward of parish assets and is fully responsible for protecting the use of these assets [12]. The parish priest with the Arch Diocese's approval can form a special team to assist in the accountability of assets.

Paragraph 12 of the Parish Financial and Accounting Guidelines of the Arch Diocese of Makassar states that the legal entity that is responsible for the parish's financial is PGPM specifically its treasurer. Moreover, the Financial Board can create financial team for parish which assigned to aid in the management of the parish financial starting from the $\mathrm{BCC}$ to the categorical groups. In relation to the terms above, the researcher conducted an interview and confirmed through documents that at X Parish, the person in charge of the finance was carried out by the PGPM, which was proven through a Decree by the Arch Diocese of Makassar. Furthermore, by analysing documents that are related to the implementation of financial process assistance, it can be concluded that the assistance has been carried out by the Financial Team of X Parish to the categorical groups. A few of the leaders and treasurers confirmed and stated:

"Yes, it is correct that training and guidance was done by the financial team of the parish. However, in all honesty, this was the first time we've had training like this. It was difficult for some of us who are not familiar with financial problems and the use of programs in carrying out financial records and reporting" (Mr. A from BCC 1). 
"The assistance in the preparation of financial reports that was provided to us has helped us to record through the system rather than having to manually record everything in a book" (Mr. B from BCC 2).

"The assistance that we provide was in accordance with the terms of the preparation of parish financial report. Thus, each BCC is responsible to provide a financial report which will later assist the parish in reporting the financial report to the Arch Diocese. Most of the materials provided are aligned with Parish Financial and Accounting Guidelines of the Arch Diocese of Makassar with only a few adjustments to simplify the process based on the needs of the BCC and parish" (Mrs. AL - Treasurer 1 of X Parish).

\section{c) Guidelines for the Preparation of BCCs' Financial Reports}

In accordance to paragraph 18 of the Parish Financial and Accounting Guidelines of the Arch Diocese of Makassar, the financial report consist of a few reports starting from the monthly Cash Flow Statement, which will need to be reported at the latest on the tenth day of the following month; and the annual financial statements which consist of Balance Sheet, Activity Report, Profit and Loss Report, Notes on Financial Statements, Budget Realization Report, Budget Report as well as Investment Budget Plan for the coming year.

The preparation of Cash Flow Statement, Balance Sheet and Activity Report requires complete financial information from the BCCs. Therefore, each $\mathrm{BCC}$ is required to inform its Cash Flow Statement, Balance Sheet and Activity Report to the Parish. Based on this, the researcher confirms the total and types of reports that was submitted to the X Parish which has resulted in the following matters:

1. From a total of $23 \mathrm{BCCs}$ in the X Parish, they have all submitted their Financial Reports, even though it was just in the form of simple cash book. None of them had succeeded in submitting the report according to the standard.

2. The main obstacles that were faced by the leaders and treasurer were:

a. The incapability to prepare financial report according to the guidelines.

b. The incapability on operating simple computer software such as Microsoft Excel.

c. Lack of understanding from the leaders and treasurers from the importance of creating the report as part of accountability to the church.

d. Some of the leaders and treasurers think that all assets that were managed by the BCC are owned by the BCC and not part of the Parish. This leads to the thoughts that reporting financial activity to the Parish is not part of their responsibility.

e. The difficulty in preparing proves of documents of the income and expenses.

"We do not have the knowledge about what the financial reporting regulations are. Before the change of parish priest, we were never required to prepare monthly or quarterly reports. We were only asked to present our BBC financial position at the end of each year. It makes me questioned the actual regulation that will be made by the current Pastor." (Mr. AA - Chairman of BCC SB)

"I do not know how to operate computer/ laptop. This whole time I recorded manually using the cash book and never really kept the all the invoices. The important thing for me is that all the money and assets that belong to the BCC are all safe." (Mrs. AT Treasurer of BCC SE). 
"If the management of BCCs must carry out these difficult tasks, it will have an impact on the absence of people who are willing to serve and carry out their responsibilities as leader or treasurer of the BCCs. We all have daily job apart from serving in the church. We felt that it is difficult if we were ever required to prepare another financial report again." (Mrs. T - Treasurer of BCC SH).

"All this time, I always thought that the job that we did in BCC is part of our responsibility to the congregation and member of $\mathrm{BCC}$ because all the money and assets that were collected came from the people in the BCC itself. Why do we still have to report it to the parish? To date, the Parish has never required us to prepare financial statement. This has only started since the new Pastor.” (Mr. F - Chairman of BCC SF).

"Money or assets that were collected in the BCC is the money or the members, thus, it is fair for us to think that we can use it for the purpose of the BCC. Do we require reporting all the activities to the parish? As long as we are able to fulfil our responsibility to deposit all of the offerings and donations to the parish, I think that it is not necessary to report the income and expenses to the parish." (Mr. VN - Chairman of BCC SGG).

"The parish's treasurer requires us to submit all the invoices of income and expenses while we do not always have them. For instance, if we are donating money to a member who lost a family member, is it ethically correct if we ask the member to sign a receipt as a prove of donation expense?" (Mr. F - Chairman of BCC FC).

3. According to Code of Canon Law No. 1282 and No. 1258, it is stated that the management of ecclesiastical assets is pursued according to its purpose, because these assets are managed in the name of the Church. In addition, regarding the use of money in BCCs, some BCCs are not in line with the basic principles and criteria suggested in paragraph 14 of the Parish Financial and Accounting Guidelines of the Arch Diocese of Makassar. Based on paragraph 14 of the Parish Financial and Accounting Guidelines of the Arch Diocese of Makassar, the use of money:

a. Must be in harmony with the interests, image, and identity of the Church.

b. In accordance with pastoral needs.

c. Proper, reasonable, not excessive, and efficient.

d. Comply with laws and regulations.

Based on the principles, the researcher obtained confirmation and information from the treasurer of X Parish who found the use of money from several BCCs that was not in accordance with these principles. The parish treasurer obtains this information through reports from $\mathrm{BCC}$ members as well and from the BCCs' cash flow report.

"Yes, we found that there were several BCCs who owned assets and made asset purchases using BCC cash, whose purpose was not in line with the principles of worship or service. There was even one BCC who bought land, instead of for the benefit of the BCC members, whose ownership was in the name of the chairman of the $\mathrm{BCC}$ from the previous period. Other findings include there were several BCCs who did not report their overall income from the BCC worship tithe and live streaming mass during the Covid-19 pandemic; it was also found that $\mathrm{BCC}$ was conducting debtreceivables transactions with its members; the $\mathrm{BCC}$ buys assets and carries out 
activities on behalf of the BCC and the parish, which are not in accordance with the principle of using money." (Mrs. VD - Treasurer 2 of X Parish)

"We have followed up the inconsistencies in the use of money by several BCCs by providing an understanding to the BCCs members. In the case of purchasing assets on behalf of the BCC as part of X Parish, we have appealed to the chairman of the BCC to sell or change the name of the ownership of the assets to become in the name of the Church or Makassar Archdiocese. Meanwhile, for reporting, especially the reporting of income from tithe collection, we have asked every BCCs chairmen to improve their reports and all receipts of the tithe/collection from BCCs' services are reported and deposited to the parish.” (Pastor DL - Pastor of X Parish)

"For several cases that occurred regarding the use of money and other assets, both in our BCC and in other BCCs, to be honest we do not know some of these rules. For example, in our $\mathrm{BCC}$, there are accounts receivable transactions between $\mathrm{BCC}$ and members who need funds. So far, BCC members can lend some money from BCC and return them at a predetermined time. As the chairman of BCC, I didn't know that there was a rule which prohibits the occurrence of debts between $\mathrm{BCC}$ and its members. The desire to help members can be channelled through social donations, which are legitimate to be removed from the BCC treasury. "

(Mr. AB - Chairman of BCC SH)

4. In early 2020, X Parish has submitted the parish's financial statements to the Arch Diocese of Makassar. Even though the contents of the financial statements have not shown the actual situation (the total assets of BCCs have not been reported completely), X Parish has tried to follow the guidelines.

"Since early 2020, we urged the management of BCCs to report their BCCs financial position according to the Parish Financial and Accounting Guidelines of the Arch Diocese of Makassar. Every BCC is required to make a cash inflow and cash out statement including transaction evidence, as well as a list of inventory reports and assets. Cash in and cash out reports will make it easier for the parish treasurer to prepare balance reports and activity reports in accordance with what happens in all BCCs. In its implementation, it was certainly not easy because we must provide an explanation and understanding to the BCCs management that BCCs assets are the assets of the Church, and therefore all use and procurement must be known by the parish. We have received criticism and rejection from certain BCCs management, especially because the obligation to make BCC financial reports was not carried out in the previous leadership of X Parish. This does not deter our intention to improve the understanding of the congregation and BCCs administrators in the use and management of Church assets, and we will continue to help through the Parish Finance Team. " (Pastor DL-Pastor of X Parish)

"We have finished examining the first semester financial reports submitted by the BCCs to the parish. At first, I felt exhausted and confused about where to start because of the incomplete data and evidence of expenses and income. However, after a long discussion with pastors and the financial team, we have analysed every BCCs financial report and we have returned the analysis results to all BCCs for improvement. The 
analysis contains deficiencies that must be addressed in the financial statements for the second semester of 2020 and subsequent periods. Hopefully everything can be understood by the BCCs management and carried out together with a spirit of service." (Mrs. VD - Treasurer 2 of X Parish)

\section{d) What's Next?}

After the parish treasurer has finished analysing the financial statements (cash in and cash out) of each BCCs, the parish priest asks the Parish Finance Council for consideration on what steps to take next to facilitate the preparation of financial reports. The finance team decided to provide training and assistance in the preparation of financial reports to the chairperson and treasurer of the BCCs. Prior to this training and mentoring, the finance team created a simple program using Microsoft Office Excel, which is expected to facilitate filling in cash in and out transactions for each $\mathrm{BCCs}$, even to the preparation of a financial position report.

Some BCCs administrators felt that it was easier after participating in this training activity, but other BCCs administrators still found it difficult to use the Microsoft Excel program which the finance team considered quite simple. The financial team and the parish priest understand this situation because starting something new is certainly not easy. There are many adjustments that need to be made both by the BCCs management and by the finance team and parish treasurers. As stated in Ranglin, the experience of the BCCs treasurer will affect his/her understanding regarding the preparation of BCCs financial statements, which means that new treasurers will certainly find it difficult to prepare financial reports according to the set guidelines [13].

The expressions of the experiences and opinions of the BCCs management are as follows.

"Recording cash receipts and disbursements, as well as recording BCC inventory and assets is made easier by using the formula provided by the finance team in Microsoft Excel. In the future it will become easier to collect our financial records to the parish because every transaction is recorded in a more structured manner. The consequence is that the treasurer must be more active in recording every receipt and expense transaction and collect transaction evidence." (Mr. JH - Chairman of BCC YY)

"To be honest, the chairman of BCC and I are not used to using computers or laptops. The laptop used for this training was borrowed from a member of the BCC. It seems that it will be difficult for us to record every income and expense transaction, especially recording and reporting the amount of our BCC assets. Yeah, for that we will probably ask for help from BCC members who are capable and understand how to operate this program properly. "(Mrs. AD - Treasurer of BCC SAR)

"After participating in the training and mentoring, I am still confused about how to calculate the depreciation of fixed assets owned by BCC. As someone who does not understand accounting, I doubt that our BCC is able to report the inventory and asset amount of BCC properly and correctly. After all, why does BCC need to report assets in such detail? The important thing is that we report assets, the rest doesn't need to be counted again. "(Mr. JA - Treasure of BCC PTR)

Research by Simatupang, Gunarso, and Kuntara (2019) suggests that dioceses and parishes should provide regular training to treasurers and heads of BCCs so that the financial reporting 
process can run better [14]. For the next stage, the parish priest and the financial team are always opened to providing assistance to every BCC who needs it. Every Saturday and Sunday the treasurer and head of the finance team open a schedule for consultation and assistance in the preparation of BCC financial reports. In the future, it is expected that each $\mathrm{BCC}$ can submit financial reports in the form of cash receipts and payments, as well as a report on financial position. It aims to support the parish in compiling and reporting parish financial reports to the Arch Diocese, in full and according to recommended guidelines.

\section{Conclusion}

Qualitative research using the phenomenology method provides an opportunity for researchers to describe the experiences that have been experienced by parties who have experienced a certain phenomenon [9]. In the research conducted at X Parish, it was found that the BCC has an obligation to make financial reports and report them to the parish. This happened due to the increasing need for the Arch Diocese to know about asset management, especially the finances of each parish [15]. However, based on the results of interviews with the chairperson and treasurer of the BCCs, some BCCs still refused. As stated in Yasmin, Haniffa, and Hudaib (2013), one of the main issues and causes for the low level of internal financial accountability in a non-profit organization is the lack of volunteers who are experts in financial reporting [16].

As for BCCs who are willing to carry out these obligations, they are committed to continuing to learn and improve their understanding of the practice of preparing BCCs financial statements. If BCCs continue to refuse to make financial reports, the Parish / Church may end up experiencing errors in recording assets and misuse of assets [17]. Therefore, pastors and parish treasurers are always committed to providing understanding to BCCs members about the importance of BCCs financial reports so that parish financial reports can be prepared in accordance with established guidelines, the Parish Financial and Accounting Guidelines. As Gitee et.al stated that financial training will boost the effectiveness of financial management [18], the X Parish will supply assistance and supervision (from the financial team to the BCCs) continuously. According to Ovando (2020), Parishes are able to get assistance from external parties to provide suggestions and assistance to BCCs regarding the importance of financial transparency and asset management [19]. In the end, each parish can create a culture of accountability and transparency in accordance with the direction of Pope Francis, namely the rooted disclosure of information from all elements of the Church so that truth and justice are reflected [20].

\section{References}

[1] PM. Mwaura, "The effects of Financial Accountability on the Performance of NonGovernmental Organizations in Kenya," University of Nairobi Research Archive.. 2013.

[2] M. Silaen, "Analysis of The Quality of The Application of SFAS 45 Financial Statements in St Peter's Catholic Church Parish Field East," Jurnal Manajemen STIE LMII., vol 4, no.1, 2018.

[3] F. Randa, "Akuntabilitas Keuangan dalam Organisasi Keagamaan (Studi Etnografi pada Sebuah Gereja Katolik di Tanah Toraja," Jurnal Sistem Informasi Manajemen dan 
Akuntansi., vol. 9, no. 2 pp 59-83, 2011.

[4] RJ. Kaslyn, "Accountability of Diocesan Bishops - A Significant Aspect of Ecclesial Communion," Jurist., vol. 67, pp. 109-152, 2007.

[5] BK. Mensah, "Accountability and internal control in religious organisations: a study of Methodist church Ghana," African Journal of Accounting., vol.5, no. 2, 2016.

[6] R. West and C. Zech, "Internal Financial Controls in the U.S. Catholic Church," Villanova University., 2007.

[7] R. Njoroge, "Effectiveness and Challenges in Evangelization in the Small Christian Communities in the Catholich Church in Vihiga County Kenya," South Asian Research Journal of Humanities and Social Sciences., vol. 1, no. 2 pp. 173 - 178, 2019.

[8] BM. Nzisi, "Leadership in small christian communities and its effect on parish strategy: A case of St Francis Catholic Church in Kasarani, Nairobi County," United States International University-Africa Digital Repository., 2017.

[9] HR. Pollio, TB. Henley, and CJ. Thompson, "The phenomenology of everyday life," Cambridge University Press., p. 60, 1997.

[10] BE. Neubauer, CT. Witkop, L. Varpio, "How phenomenology can help us learn from the experiences of others," Perspective on Medical Education.,vol. 8, pp 90 - 97, 2019.

[11] Arch Diocese of Makassar, "Pedoman Keuangan dan Akuntansi Paroki (the Parish Financial and Accounting Guidelines)," Arch Diocese of Makassar., 2013.

[12] L. Rasaian, "The Collaboration between The Parochus and The Parish Finance Council in The Protection of Parish Property: practical Reflections on the Relation between Canons 532 and 537 of the 1983 Code of Canon Law," uO Research Saint Paul University., 2014.

[13] CG. Ranglin, "The Relationships between Years of Experience, and Church Size, and The Reported Use of Financial Reporting Practices and Internal Controls; A Multiple Regression Study," Proquest Dissertations Publishing Capella University., 2014.

[14] BA. Simatupang, GF. Gunarso, AD. Kuntara, "Implementation of Microsoft AccessBased Accounting Software in Catholic Church in Yogyakarta,' Icore Journal., vol.5, no. $1,2019$.

[15] C. Biermeier, "Believing without Contributing? Developing a Theoretical Model for The System of The Church Financing of the Roman Catholic Church in Germany," University of Gloucestershire Research-PhD Thesis., 2019.

[16] S. Yasmin, R. Haniffa, M. Hudaib, "Communicated Accountability by Faith-Based Charity Organisations," Journal of Business Ethics-Springer., vol. 122, No. 1, 2014.

[17] MJ. Kirby, "A Qualitative Study on Internal Control Usage and Financial Accountability among Baptist Churches in North Georgia," Liberty University LibraryPhD Thesis., 2020.

[18] EW. Gitee, HK. Mburu, A.Muhavani, "Determinants of Effective financial management in Catholic Church managed health institutions in Kenya," African Journal of Emerging Issues., vol. 1, No. 9, 2019.

[19] CM. Ovando, "What Kind of Transparency for the Church? Proposing Operational Tranparency for Processes, Solutions, and Decisions in the Catholic Church," Church, Communication and Culture Journal - Taylor Francis Online., Vol. 5, No. 2, 2020.

[20] S. Kalapurackal, JD. Vidayapeeth, "An Ethical Analysis of Transparency and Accountability in Church Administration," Asian Horizons Journal., vol 14, No. 2, 2020. 